A.A. Vorotnikov, Honorary Employee of Higher Professional Education of the Russian Federation, Doctor of Sciences (Law), Professor of the Theory of State and Law Department, Saratov State Academy of Law

\section{REVIEW OF THE} COURSE OF LECTURES: O.I. Tsybulevskaya, T.V. Milusheva. Theory of State and Law. Saratov:

Povolzhsky Institute of Management named after P.A. Stolypin, Branch of the Russian Presidential Academy of National Economy and Public Administration, 2018. 244 pp.
А.А. Воротников, почетньй работник висшего профессионального образования Российской Федерачии, доктор юридических наук, профессор кафедры теории государства и права Саратовской государственной юридическй академии

\section{РЕЦЕНЗИЯ}

НА КРАТКИЙ КУРС АЕКЦИЙ: О.И. Цыбулевская, Т.В. Милушева. Теория государства и права. Саратов:

Поволжский институт управления имени П.А. Столыпина филиал РАНХиГС, 2018. - 244 с.

$\Gamma$ - осларство и право представмяют собой объекты повышенного соџиацьного интереса. Это обусловлено их важным значением в жизни отАеАьного инАивиАа и общества в целом. Изучение закономерностей возникновения, становления и развития этих феноменов явцяется объективной закономерностью. Наука призвана рассматривать основные явления государственно-правовой жкизни во всем их многообразии, выявцять наиболее значимые тенденџии, закономерности и недостатки общественного развития, предкагать действенные программы их преодоления.

В теории государства и права как части обществознания и основой практической 
юриспруденции изучаются государство и право в их единстве. Вопросы о сущности этих явлений до сих пор не могут быть обозначены как решенные и нередко рождают новые Аискуссии.

В недалеком прошиом учебные пособия по теории государства и права создавались в основном комлективами авторов, гАе Аоля кажАого участника не быма очевидной. Сегодня появицись авторские разработки, к числу которых принадлежит краткий курс мекций О.И. Цыбулевской и Т.В. Милушевой.

Аекции всегда воспринимаются студентами как наиболее адекватное отражение непростого теоретико-правового материала. Позиџия авторов мекщий нередко отражают традиции той научной школы, приверженцами которой они явцяются, с бережным отношением к Аостигнутым научным результатам своих комег.

Теория государства и права как наука и дисциплина начинается Аля стуАентов юридических вузов на 1-м курсе, когда происходит овладение категориальным аппаратом юриспруденџии. Этот проџесс изучения не требует сложного наукообразного изцожения. Аоступность глубокого теоретического материала дия восприятия студентов свидетельствует о высоком профессионализме О.И. Цыбулевской и Т.В. Милушевой, которые руководствовались классической схемой преподавания предмета, избегая некоторых неоднозначных тем, нередко «размывающих» суть науки. Системность - отличительная черта Аанного курса, в котором все мекции органически связаны по структуре и содержанию.

Цели и задачи курса «Теория государства и права» предопределили структуру учебного пособия. Оно состоит из авторского обращения к читателям, шестнадџати мекџий и закмючения. Издание в конџентрированной форме содержит сведения о теории государства и права, обобщающие современные Аанные о происхождении этих соџиальных институтов, новых формах и типах права и государства, путях формирования правового государства и гражАанского общества, иных проџессах и явлениях. Многие проџессы государственно-правовой жкизни претерпели в последнее время изменения и требуют пересмотра ряда привычных представлений. Уход от идеологии, на которой многие десятилетия базировалась государственно-правовая наука, обусловливает применение новых методологических оснований. Вместе с тем авторы постарались сохранить то ценное, непреходящее, что было сформулировано за рамками идеологических догматов, все то, что составцяет кладезь государственно-правовой мыски.

Особенной методологической ценностью отмичается первая мекция о преАмете и методе теории государства и права, из которой студент получает преАставление о том, что такое наука в целом и теория государства и права в частности. ЗАесь освещаются такие вопросы о классификации наук, их делении на естественные и общественные, важной роли юридических наук в жизни общества.

Определяя предмет теории государства и права, авторы справедливо считают, что его составцяют общие закономерности возникновения, развития и функционирования государства и права, органически связанные с ними 
иные социальные явления и процессы, а также основные понятия и категории юриспруденџии (с. 7). Исследуя методологию теории государства и права, авторы утверждают, что она преАставцяет собой систему особых приемов и способов изучения общих закономерностей возникновения, развития и функщионирования государственно-правовых явлений (с. 9). В учебном пособии предмагается кмассифицировать методы теории государства и права на всеобщие, общенаучные и частнонаучные. Рассматривая функции науки теории государства и права, авторы выдвигают тезис о том, что это те направления ее Аействия, которые требуются Аля решения стоящих переА ней задач (с. 15).

Все категории и понятия теории государства и права, которыми Аолжен овладеть студент по окончании обучения, отмечены полужирным шрифтом. Это фокусирует внимание, создавая определенную систему «опорных сигнацов».

Авторы твердо отстаивают материалистические основания теории государства и права, рассматривая их связь с материальными условиями жизни общества, классовыми и национацьными интересами. Вместе с тем не остаются без внимания и синергетические - случайностные, произвольные предпосылки формирования явлений, позволяющие «понять проџессы самоуправления и управления в государственно-правовой сфере» (с. 12).

С плюралистических позиџий анализируются вопросы происхожАения государства и права. О.И. Цыбулевская и Т.В. Милушева пытаются расширить научный кругозор студентов, освещая богатство государственно-правовой мысли в мировом масштабе. Критически освещаются мнения преАставителей разцичных теорий относительно происхождения государства и права (теологической, патриархальной, теории насилия, Аоговорной, ирригационной, психологической, органической и марксистской Аоктрин). Подчеркивается, что «современное объяснение причин возникновения государства опирается на Аостижения археологии, этнографии, истории, которые положены в основу потестарной, или кризисной, теории» (с. 21).

Вопрос о том, что есть государство, является краеугольным, определяющим иные явления в науке о государстве и праве. В зависимости от того, каковы функщии государства, его задачи, методы их осуществления, можно судить о фактическом политическом режиме и форме правления в тот или иной период. Определяя государство, авторы справеАливо считают, что это «организация политической власти, офиџиацьно охватывающая и представмяющая все общество в пределах определенной территории, содействующая преимущественному осуществлению конкретных интересов (классовых, общечеловеческих, религиозных, национальных и др.)» (с. 28). Типология государства представлена двумя подходами - формаџионным и цивилизационным.

Второй макропроблемой курса является выяснение сущности и определения права. С этих позиций рещензируемая работа также представцяет значительный научный интерес и обоснованно подтверждает статус учебного пособия. Последовательно отстаивая идею многопомярности суждений, ав- 
торы знакомят студентов с теологической и естественно-правовой теориями, исторической и психологической школами права, определяя своеобразие и Аостоинства каждой из конџепџий правопонимания. Используя позиџии известных ученых-правоведов, они подчеркивают, что «нормативный подход четче Аругих характеризует такое свойство права, как общеобязательная нормативность, обеспечивает определенность правоприменительной практики, фиксированность мер государственного принуждения, укрепления законности и правопорядка» (с. 93). Обобщая и обосновывая признаки права, авторы Аают собственное определение этого феномена. Вполне справедииво считается, что «право - это система общеобязательных, формально-определенных правиц поведения, установленных и охраняемых государством, направленных на регулирование обшественных отношений» (с. 95). Конструкция привеАенного определения носит четкий, могичный характер и отражает максимум признаков права. Считается, что право имеет Авоякую сущность: оно выступает в качестве инструмента выражения как классовых, так и общесоџиальных интересов.

О.И. Цыбулевская и Т.В. Милушева, убедительно аргументируя свои выводы, позволяют студентам составить устойчивое преАставцение относительно рассматриваемых государственно-правовых явлений. ОАнако, но на наш взгляА, учебное пособие выиграмо бы при имлюстрировании наиболее

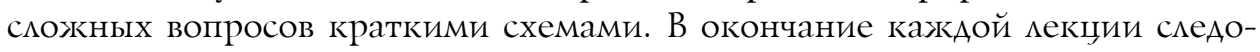
вало вкцючить вопросы Аля самоконтроля и рекомендовать Аополните ьные монографические источники известных правовеАов. К сожалению, не получици отАельного освещения вопросы юридической и законодательной техники. Видимо, авторы были ограничены необходимостью краткости изможения.

В рамках программы курса и с учетом требований преподавания авторами издания уАалось в Аоступной форме раскрыть сложные проблемы юриспруАенции. Курс мекций передает главное и необходимое, что нужно знать о теории государства и права. Именно поэтому он может быть рекомендован не только студентам и аспирантам юридических вузов, но и всем интересующимся государственно-правовой проблематикой. В кратком курсе мекщий по теории государства и права отражается богатый педагогический опыт авторов, квинтэссенция научного понимания Аисциплины. 